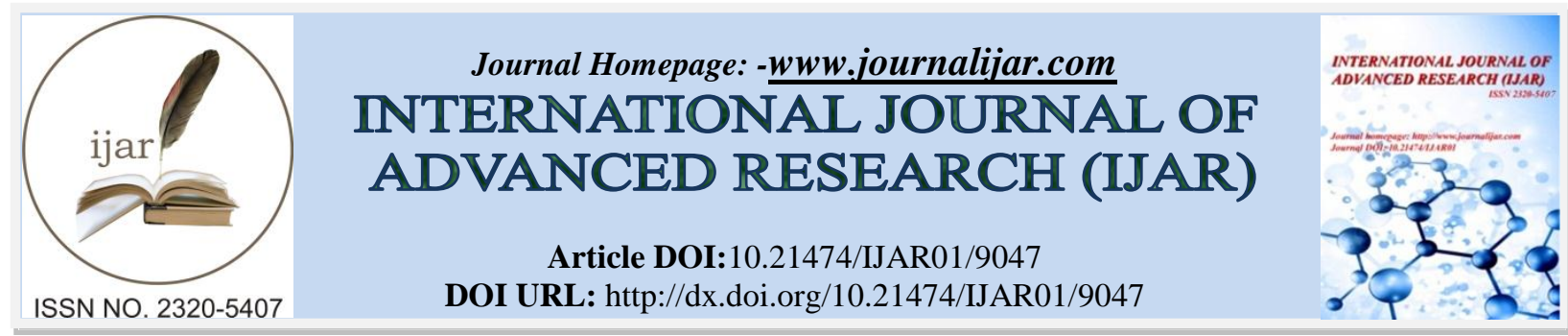

RESEARCH ARTICLE

\title{
CHARACTERIZATION OF PARTIALLY PURIFIED MILK-CLOTTING KESINAI (STREBLUS ASPER) PROTEASE.
}

Pagthinathan Mylvaganam ${ }^{1}$ and Hasanah M. Ghazali ${ }^{2}$.

1. Faculty of Agriculture, Eastern University, Sri Lanka, Vantharumoolai, Chenkalady, Batticaloa 30000, Sri Lanka.

2. Faculty of Food Science and Technology, University Putra Malaysia, UPM 43400, Serdang, Selangor, Malaysia.

\section{Manuscript Info}

…......................

Manuscript History

Received: 12 March 2019

Final Accepted: 14 April 2019

Published: May 2019

Key words:-

Streblus asper, characterization, protease activity, milk- clotting activity.

\section{Abstract}

Proteases with milk clotting can be isolated from plant sources and this study kesinai (Streblus asper) leaves contain a protease, which could be used to coagulate the milk for the alternative source for calf rennet. The present investigation was undertaken to characterize the partially purified kesinai protease. The enzyme function optimally at $60{ }^{\circ} \mathrm{C}$ and $\mathrm{pH} 7.4$ and it showed higher temperature stability at $-10{ }^{\circ} \mathrm{C}$ and $4{ }^{\circ} \mathrm{C}$. It retained more than $98 \%$ of its activity 7 days after storage at both -10 and $4{ }^{\circ} \mathrm{C}$. The enzyme was inhibited by PMSF and trypsin inhibitor by 98\% and $95.87 \%$ of initial activity, respectively. However, antipain, pepstatin A, N-ethylmaleimide, EDTA, O-phenanthroline and $\beta$ mercaptoethanol showed no significant inhibitory effect suggesting the presence of serine residue at the active site. $\mathrm{Ca}^{2+}$ had a slight stimulating effect on the enzyme activity. On the other hand, $\mathrm{Hg}^{2+}, \mathrm{Zn}^{2+}$ and $\mathrm{Pb}^{2+}$ had inhibitory effects on the enzyme activity. The enzyme was also partially inhibited by $\mathrm{Mg}^{2+}, \mathrm{Co}^{2+}, \mathrm{Cu}^{2+}, \mathrm{Ni}^{2+}$ and $\mathrm{Al}^{3+}$. Kesinai protease exhibited the highest specific activity towards azo- casein compared to casein, haemoglobin, bovine serum albumin (BSA) and gelatin. The protease also had a $\mathrm{K}_{\mathrm{m}}$ of $2.6 \mathrm{mg} / \mathrm{mL}$ for azo- casein while Milk clotting activity of kesinai was lower than commercially produce mucor rennet.

Copy Right, IJAR, 2019,. All rights reserved.

\section{Introduction:-}

Proteases constitute one of the most important groups of enzyme both industrially and academically (Rao et al., 2009). Among the vast number of proteases chymosin (EC 3.4.23.4) like milk-clotting proteases are the primary active agents in the cheeses industry (Shah et al., 2014). Calf rennet has been widely used as a milk-clotting enzyme for cheese preparation (Mohamed Ahmed et al., 2009). Recent growths in the cheese in the cheese industry and scarcity on calf rennet have stimulated the research for milk clotting enzyme from alternative sources (GutiérrezMéndez et al., 2019; Elsamani et al., 2014; Jacob et al., 2011). Milk clotting can be achieved by numerous proteases from various sources like animals, plants, microbial and genetically engineered (Shieh et al., 2009). Many plants are producing rennet like proteinases, which can be substitute the calf rennet (Nasr et al., 2016; Egito et al., 2007). Plants like enzyme papain, ficin, bromelain and cardosin (Cynara sp) are used to coagulate the milk (Baraka Abo El-

Corresponding Author:-Pagthinathan Mylvaganam.

Address:-Faculty of Agriculture, Eastern University, Sri Lanka, Vantharumoolai, Chenkalady, 
Yazeed et al., 2017; Roseiro et al., 2003). It has been also been reported, plant coagulum such as aqueous extracts of Cynara cardunculus, Solanum innacum, Centaurea calcitrapa and Onopordum turcicum have been used for years in the manufacture of cheeses (Silva and Malcata 2000 ; Silva et at., 2002).

Streblus asper is a small tree known by various names, e.g. Kesinai, Bar-inka, Berrikka, Rudi, Sheora and Koi (Rastogi et al., 2006). It is commonly found in the drier parts of India, Malaysia (Penang, Perak, Kedah, Kelantan and Perlis) and Andaman Islands (Taweechaisupapong et al., 2000; Rastogi et al., 2006). The milk clotting properties of S. asper was identified in 1961 (Roseiro et al., 2003). Idris et al. (1999) and Senthilkumar et al. (2006) were also reported that the plant $S$. asper contains a protease, which can be used to coagulate the milk.

The milk coagulant aspartic proteases (EC 3.4.23.X) and cynarases (Cynara cardunculus) are well studied and documented their structure and mechanism (Davies, 1990 ; Chitpinitoyl and Crabbe, 1998 ; Chazarra et al., 2007). But kesinai protease has only been studied for extraction and purification techniques, and also the protease has been proved to have higher thermal stability compare to the commercial rennet (Manap et al., 1992; Senthilkumar et al., 2006). However, detail and accurate studies to determine the characteristic of the enzyme have not yet been carried out. Therefore the main objective of the present work was to characterize kesinai protease, obtained from Streblus asper for the commercial application.

\section{Materials and methods:- Enzyme preparation}

Kesinai extract was prepared by grinding $20 \mathrm{~g}$ of fresh leaves in $100 \mathrm{mM}$ Tris $\mathrm{HCl} \mathrm{pH}$ at 7.4 and filtered through a muslin cloth. Then extract was centrifuged at 10,000 $\times \mathrm{g}$ for $30 \mathrm{~min}$ at 4C (Model 32BL80, Dynamic Corporation of America, New Hartford, Connecticut, USA). Then the supernatant was further purified by using combinations of acetone precipitation, ion exchange and gel filtration chromatography techniques described by Michail et al. (2006) and Senthilkumar et al. (2006).

\section{Determination of protease specific activity}

Partially purified proteas was assayed using azo-casein (Sigma-Aldrich, USA) $1 \mathrm{~mL} ; 0.5 \%$ (w/v) in $0.1 \mathrm{M} \mathrm{Tris-HCl}$ buffer, pH 7.4 at $60{ }^{\circ} \mathrm{C}$ as described by Sarath et al. (1989). The enzyme reaction was stopped by addition of $0.3 \mathrm{~mL}$ Trichloroacetic acid (TCA) $(10 \% \mathrm{w} / \mathrm{v})$, followed by micro-centrifugation at $10,000 \times \mathrm{g}$ for 10 min (Microfuge 18 centrifuge, Germany) and absorbance measurements at $410 \mathrm{~nm}$ and one unit of caseinolytic activity is defined as the amount of enzyme causing an increase in absorbance by 0.01 . A control was run by adding the boiled enzyme solution.

\section{Protein determination}

Protein concentration of enzyme samples in each step was determined by the method of Lowry et al. (1951). Bovine serum albumin (Sigma-Aldrich, USA) was used as a standard.

\section{Optimum temperature and temperature stability}

In order to determine the optimum temperature of partially purified kesinai protease activity was assay from 20 to $100{ }^{\circ} \mathrm{C}$ for $20 \mathrm{~min}$ at $\mathrm{pH} \mathrm{7.4.} \mathrm{Controls} \mathrm{were} \mathrm{done} \mathrm{for} \mathrm{each} \mathrm{temperature.} \mathrm{Temperature} \mathrm{stability} \mathrm{of} \mathrm{partially} \mathrm{purified}$ kesinai protease was analysed by incubating at various temperature $-10,4,25,50,60$ and $70{ }^{\circ} \mathrm{C}$ for $24 \mathrm{hr}$. From each case aliquots were withdrawn at $3 \mathrm{hr}$ intervals to test the remaining activity prevailing at standard conditions. A solution of non-heated enzyme was used as the control (Bougatef et al., 2007).

\section{Determination of optimum pH}

To determine optimum $\mathrm{pH} 0.05 \%$ (w/v) of azo-casein solution was prepared in $0.1 \mathrm{M}$ sodium acetate ( $\mathrm{pH} 3.0$ - 5.0), phosphate ( $\mathrm{pH}$ 6.0- 7.0), Tris- $\mathrm{HCl} \mathrm{pH}$ (7.0- 9.0) and carbonate buffer (pH 10.0-11.0) buffers. Protease activity was studied in the $\mathrm{pH}$ range of 3.0-11.0 at the optimal temperature (Bougatef et al., 2007).

\section{Substrate specificity}

Impact of various natural substrate like casein, haemoglobin, bovine serum albumin (BSA) and gelatin (All from Sigma-Aldrich, USA) was studied according the method described by Khan et al. (2008). The hydrolysing activity of the partially purify enzyme was determined using natural substrate at $0.5 \%(\mathrm{w} / \mathrm{v})$ using standard protease assay and azo-casien was used as control (100\%). 


\section{Determine the storage stability}

The enzyme was stored at -10 and $4{ }^{\circ} \mathrm{C}$ for 7 days. It was also done in order to investigate storage stability. Samples were taken after $6,12,24,48,72,96,120,144$ and $168 \mathrm{hr}$ and the protease activity was determined by standard protease assay. Boiled enzyme was used as controls for this assay (Raposo and Domingos, 2008).

\section{Effect of protease inhibitors on protease activity}

The effect of proteases inhibitors on the protease activity was determined by pre-incubating the protease preparation with the inhibitor at the optimum temperature for $1 \mathrm{hr}$. The residual activity was estimated by the standard protease assay. Tripsin inhibitor (Sigma-Aldrich, USA) $(2 \mathrm{mg} / \mathrm{ml})$, phenylmethylsulphonyl fluoride (PMSF), antipain, pepstatin A, N-ethylmaleimide, ethylenediaminetetraacetic acid (EDTA), O-phenanthroline and $\beta$ mercaptoethanol (All from Merck KGaA, Germany) were dissolved at a concentration of $2 \mathrm{mM}$. A control was run by pre-incubating the protease preparation with the solvent used to dissolve the inhibitors (Zotos and Taylor, 1996).

\section{Effect of various metal ions}

Impact of various metal ions $\left(\mathrm{Li}^{+}, \mathrm{Mg}^{2+}, \mathrm{Al}^{3+}, \mathrm{Ca}^{2+}, \mathrm{Ni}^{2+}, \mathrm{Co}^{2+}, \mathrm{Cu}^{2+}, \mathrm{Zn}^{2+}, \mathrm{Ba}^{2+}, \mathrm{Hg}^{2+}\right.$ and $\left.\mathrm{Pb}^{2+}\right)$ on the enzyme catalytic effect was studied by pre-incubating at $60{ }^{\circ} \mathrm{C}$ temperature for $1 \mathrm{hr}$. Partially purified enzyme was containing a specified ion at $5 \mathrm{mM}$ final concentration in buffer solution. After of incubation, Azo-casein was added and residual activity of the enzyme was measured. A control was run by pre-incubating the protease preparation with $0.1 \mathrm{M}$ Tris-HCl buffer, pH 7.4 (Rao et al., 2009). The inhibitory effect of $\mathrm{Zn}^{2+}, \mathrm{Pb}^{2+}, \mathrm{Mg}^{2+}, \mathrm{Co}^{2+}$ and $\mathrm{Cu}^{2+}$ was also studied at different concentrations.

\section{Determination of $\mathbf{K}_{\mathrm{m}}$}

According the method described by (Matta and Punj (1998), and Yadav et al. (2006) azo- casein was prepared in different concentrations $(0.5-20 \mathrm{mg} / \mathrm{mL})$ in $0.1 \mathrm{M}$ Tris- $\mathrm{HCl}(\mathrm{pH} 7.4)$ buffer. The purified enzyme concentration was kept constant and protease activity was determined under the assay conditions at $\mathrm{pH} 7.4$ and $60^{\circ} \mathrm{C} . \mathrm{K}_{\mathrm{m}}$ of the kesinai protease was calculated by the Lineweaver and Burk (1934).

\section{Determination of enzyme concentration on protease activity}

To determine the effect of enzyme concentration, the purified was added in range of $0-100 \mu \mathrm{g}$ of protein $/ \mathrm{mL}$ concentration of enzyme to the assay mixture and protease activity was determined under the assay conditions.

\section{Milk-clotting activity assay}

To determine the milk-clotting activity, the substrate was prepared by $12.5 \%$ skim milk (Sigma-Aldrich, USA) in $0.01 \mathrm{M} \mathrm{CaCl}_{2}$ before use, the samples were incubated for $5 \mathrm{~min}$ at $60{ }^{\circ} \mathrm{C}$ as described by Silva et al. (2002). The assay was performed by adding $0.2 \mathrm{~mL}$ of partially purify kesinai protease in to $2 \mathrm{~mL}$ of reconstituted milk. The coagulation time was determined by first appearance of visible clots at $60{ }^{\circ} \mathrm{C}$ while manually rotating the test tube from time to time. The milk clotting activity was calculated by using the following formula as indicated by Shieh et al. (2009).

\section{Results and discussion:-}

The extent of purification and characterization of an enzyme has a profound effect on product quality. The kesinai protease was purified by using acetone precipitation, ion exchange chromatography and gel-filtration chromatography techniques. After final step of purification, the partial purified kesinai protease was obtained 3.3 fold of purification with recovery of $42.3 \%$ (data not shown).

\section{Temperature and pH optima}

The optimum temperature for the kesinai protease for proteolytic activity was found to be at $60{ }^{\circ} \mathrm{C}$. The same behaviour was reported for kesinai protease by Senthilkumar et al. (2006). Raposo and Domingos (2008) working with Centaurea calcitrapa found that the milk milk clotting enzyme showing an optimum temperature at $60{ }^{\circ} \mathrm{C}$. The Partially purified enzyme active $\mathrm{pH}$ range between (pH 6-8), had optimum $\mathrm{pH}$ of 7.4. Kesinai protease showed similar observation of milk clotting protease from Solanum dubium (Mohamed Ahmed et al. 2009) and Nocardiopsis sp (Cavalcanti et al., 2004)

\section{Temperature stability}

Partially purified enzyme was stored at different temperature for $24 \mathrm{hr}$ to study the heat stability of kesinai protease (Fig. 1). The enzymes remained fully active (98\%) when the enzyme exposed for $24 \mathrm{hr}$ at $-10{ }^{\circ} \mathrm{C}$ and $4{ }^{\circ} \mathrm{C}$. The 
enzyme activity was showed higher activities about $97 \%$ for $1 \mathrm{hr}$ of incubation temperature at $25,50,60$ and $70{ }^{\circ} \mathrm{C}$. After $2 \mathrm{hr}$ incubation at 25, 50, 60 and $70{ }^{\circ} \mathrm{C}$ the activity was decreased $87.4 \%, 83.1 \%, 45.6 \%$ and $37.6 \%$ of the initial activity, respectively. When increased the incubation time, enzyme activity was gradually decreased. After 24 hr incubation at 60 and $70{ }^{\circ} \mathrm{C}$, the purified enzyme was lost most of their activity by $9.68 \%$ and $3.73 \%$ if initial activity respectively.

\section{Storage stability}

In addition the studies showed the storage of purified enzyme at temperature $-10{ }^{\circ} \mathrm{C}$ and $4{ }^{\circ} \mathrm{C}$, the enzyme activity was remained more than $98 \%$ of initial activity after 7 days of storage (Fig. 2). It has been reported milk clotting enzyme from plant origin were to be stale upon storage at $4{ }^{\circ} \mathrm{C}$. For instance Sodom apple leave extract protease was stable at $4{ }^{\circ} \mathrm{C}$ for 12 days (Ogundiwin and oke 1983). Cynara protease was also reported to maintain its activity at 4 ${ }^{\circ} \mathrm{C}$ after 14 days of storage (Heimgartner et al. 1990). The storage stability of kesinai protease at temperature studied at $4{ }^{\circ} \mathrm{C}$, compare to -10 , is more beneficial to use in area where frozen transportation and long term frozen is not available. These kinds of properties would also enable its processing to be carried out at even in the room temperature. Which could potential use as rennet substitution for producing special types of cheeses in economically attractive (Raposo and Domingos, 2008).

\section{Effect of protease inhibitors on enzyme activity}

The effect of various protease inhibitors such as chelating agent and a group of specific agent on the activity was investigated (Table 1). The enzyme was strongly inhibited by the seine protease inhibitors PMSF and trypsin inhibitor by $98 \%$ and $95.87 \%$ of its initial activity, respectively. However the enzyme activity was not significantly affected by antipain, pepstatin A N-ethylmaleimide, EDTA, O-phenanthroline and $\beta$-mercaptoethanol, The inhibitory effect of PMSF and trypsin inhibitor were clearly indicating that the presence of serine residue at the active site, confirming the existence of serine protease. Michail et al. (2006) and Bougatef et al. (2007) reported the similar result for the presence of serine protease. Rao et al. (2009) working with Bacillus circulans found that the serine protease was completely inhibited by even in lower concentration of PMSF (1 mM).

\section{Effect of metal ions inhibitors on enzyme activity}

The effect of metal ions $(5 \mathrm{mM})$ on the activity of kesinai enzyme was studied at $60{ }^{\circ} \mathrm{C}$ and $\mathrm{pH} 7.4$ by the adding of the respective ion to the assay mixture (Table 2). $\mathrm{Ca}^{2+}$ had a slightly stimulatory effect on protease activity by increasing $8.3 \%$ of its initial activity. The same result was observed for serine type protease by Khan et al. (2008). This is probably due to the activation by the $\mathrm{Ca}^{2+}$ in the enzyme activity. $\mathrm{Ba}^{2+}$ and $\mathrm{Li}^{+}$did not show any appreciable effect on enzyme activity. However, $\mathrm{Hg}^{2+}, \mathrm{Zn}^{2+}$ and $\mathrm{Pb}^{2+}$ were inhibited the enzyme activity by $8.3 \%, 16.7 \%$ and $27.5 \%$, respectively. It has also been observed that presence of $\mathrm{Zn}^{2+}$ inhibited the serine type of protease (Khan et al., 2008). Other ions such as $\mathrm{Mg}^{2+}, \mathrm{Al}^{3+}, \mathrm{Ni}^{2}+, \mathrm{Co}^{2+}$ and $\mathrm{Cu}^{2+}$ had only partial inhibitory effect on enzyme activity. The inhibitory effect of protease activity was examined using different concentration of $\mathrm{Zn}^{2+}, \mathrm{Pb}^{2+}, \mathrm{Mg}^{2+}, \mathrm{Co}^{2+}$ and $\mathrm{Cu}^{2+}$ ranging from $0.1 \mathrm{mM}$ to $5 \mathrm{mM}$, and its activity decreased as the ion concentration increased (Table 3). Although $\mathrm{Zn}^{2+}$ and $\mathrm{Pb}^{2+}$ showed, significant reduction of enzyme activity when increase the concentration as result suggesting that these two ions had more inhibitory effect than those of $\mathrm{Mg}^{2+}, \mathrm{Co}^{2+}$ and $\mathrm{Cu}^{2+}$.

\section{Substrate specificity}

The substrate specificity of kesinai enzyme showed that it was active on a variety of modified substrate azo-casein and natural protein such as casein, haemoglobin, BSA, and gelatin as shown in Table 4. Kesinai enzyme exhibited the highest activity towards azo-casein. The enzyme also showed reasonable hydrolytic activity on natural protein. Yadav et al. (2006) and Khan et al. (2008) were found that, serine type proteases are more active towards azo casein than natural protein. Although, the enzyme was able to hydrolyze fibrous protein like gelatin.

\section{Determination of $\mathbf{K}_{\mathbf{m}}$}

The enzyme behaved Michaelis- Menten kinetics with synthetic substrates (azo-casein). The effect of increasing substrate concentration on the protease reaction rate follows typical Michaelis-Menten equation with azo-casein as a substrate. The $\mathrm{K}_{\mathrm{m}}$ value of kesinai enzyme was calculated as $2.6 \mathrm{mg} / \mathrm{mL}$ at $\mathrm{pH} 7.4$ and temperature at $60{ }^{\circ} \mathrm{C}$ (Fig. 3 ). The result was quite similar to the purified milk clotting enzyme from Bacillus megaterium, it showed $\mathrm{K}_{\mathrm{m}}$ value of $2.77 \mathrm{mg} / \mathrm{mL}$ (Sastry, 1979). However, their values are higher than those obtained by Khan et al. (2008), who reported that $\mathrm{K}_{\mathrm{m}}$ value of serine type protease was $1.1 \mathrm{mg} / \mathrm{mL}$. Protease activity is also dependent on the concentration of enzyme. The nature of the kinetics with respect to the enzymes is typically hyperbolic, and at higher concentration of the enzymes the activity attains saturation (Fig. 4). 


\section{Milk clotting activity}

The study was revealed that the clotting time of partially purified kesinai protease was 25 times higher than mucor rennet. Previous study reported by Raposo et al. (2008) who mentioned that higher ration of milk-clotting activity compared to proteolytic activity was used as a more suitable rennet substitute.

\section{Conclusion:-}

In this study, the enzyme was acted optimally at $60{ }^{\circ} \mathrm{C}$ and $\mathrm{pH}$ at 7.4 and it showed higher temperature and storage stability. PMSF and trypsin inhibitor were inhibited the enzyme activity. $\mathrm{Ca}^{2+}$ enhanced effect on the enzyme activity while $\mathrm{Hg}^{2+}, \mathrm{Zn}^{2+}$ and $\mathrm{Pb}^{2+}$ showed inhibitory effects on the enzyme activity. Kesinai protease exhibited the highest specific activity towards azo- casein and it showed $\mathrm{Km}$ of $2.6 \mathrm{mg} / \mathrm{mL}$. Kesinai protease could serve as an alternative source of milk clotting enzyme for the manufacture of the cheese.

\section{Acknowledgement:-}

The authors wish to grateful to Universiti Putra Malaysia and Eastern University, Sri Lanka, which financed this study

Table 1:-Effect of protease inhibitors such as chelating agent and a group of specific agent on kesinai enzyme activity

\begin{tabular}{|c|c|l|}
\hline Protease inhibitors & $\begin{array}{l}\text { Concentration } \\
(\mathbf{m M})\end{array}$ & $\begin{array}{l}\text { Relative activity } \\
(\boldsymbol{\%})\end{array}$ \\
\hline PMSF & 02 & $2.2 \pm 0.1$ \\
\hline Trypsin inhibitors & $0.2 \mathrm{mg} / \mathrm{ml}$ & $4.13 \pm 0.2$ \\
\hline Antipain & 02 & $93.4 \pm 2.8$ \\
\hline Pepstatin A & 02 & $90.1 \pm 2.8$ \\
\hline N-Ethylmaleimide & 02 & $85.7 \pm 0.6$ \\
\hline EDTA & 02 & $90.1 \pm 1.5$ \\
\hline O-Phenanthroline & 02 & $97.8 \pm 1.4$ \\
\hline B-mercaptoethanol & 02 & $95.6 \pm 1.0$ \\
\hline & & \\
\hline
\end{tabular}

Table 2:-Effect of various metal ions $(5 \mathrm{mM})$ on kesinai enzyme activity

\begin{tabular}{|c|c|l|}
\hline Metal ions & \multicolumn{1}{|c|}{$\begin{array}{c}\text { Concentration } \\
(\mathbf{m M})\end{array}$} & $\begin{array}{l}\text { Relative activity } \\
(\boldsymbol{\%})\end{array}$ \\
\hline $\mathrm{Li}^{+}$ & 05 & $95.8 \pm 1.4$ \\
\hline $\mathrm{Mg}^{2+}$ & 05 & $50 \pm 0.3$ \\
\hline $\mathrm{Al}^{3+}$ & 05 & $77.3 \pm 1.3$ \\
\hline $\mathrm{Ca}^{2+}$ & 05 & $108.3 \pm 1.5$ \\
\hline $\mathrm{Ni}^{2+}$ & 05 & $62.3 \pm 1.4$ \\
\hline $\mathrm{Co}^{2+}$ & 05 & $50.8 \pm 0.2$ \\
\hline $\mathrm{Cu}^{2+}$ & 05 & $41.7 \pm 1.1$ \\
\hline $\mathrm{Zn}^{2+}$ & 05 & $16.7 \pm 0.7$ \\
\hline $\mathrm{Ba}^{2+}$ & 05 & $84.1 \pm 1.5$ \\
\hline $\mathrm{Hg}^{2+}$ & 05 & $8.3 \pm 0.4$ \\
\hline $\mathrm{Pb}^{2+}$ & 05 & $27.5 \pm 0.5$ \\
\hline $\mathrm{EDTA}$ & 05 & $87.9 \pm 1.1$ \\
\hline
\end{tabular}

Table 3:-Effect of different concentration of $\mathrm{Zn}^{2+}, \mathrm{Pb}^{2+}, \mathrm{Mg}^{2+}, \mathrm{Co}^{2+}$ and $\mathrm{Cu}^{2+}$ on kesinai protease activity

\begin{tabular}{|c|c|c|c|c|c|}
\hline $\begin{array}{c}\text { Concentrat } \\
\text { ion }\end{array}$ & $\begin{array}{c}\text { Relative activity } \\
(\mathbf{\%})\end{array}$ & $\begin{array}{c}\text { Relative activity } \\
(\mathbf{\%})\end{array}$ & $\begin{array}{c}\text { Relative activity } \\
(\mathbf{\%})\end{array}$ & $\begin{array}{c}\text { Relative activity } \\
(\boldsymbol{\%})\end{array}$ & $\begin{array}{c}\text { Relative activity } \\
(\boldsymbol{\%})\end{array}$ \\
\hline $\mathbf{( m M})$ & $\mathbf{M g}$ & $\mathbf{Z n}$ & $\mathbf{P b}$ & $\mathbf{C o}$ & $\mathbf{C u}$ \\
\hline 0.1 & $71.47 \pm 1.6$ & $50.15 \pm 1.4$ & $51.41 \pm 0.9$ & $68.02 \pm 1.63$ & $69.59 \pm 2.0$ \\
\hline 0.2 & $65.51 \pm 0.9$ & $47.02 \pm 2.3$ & $47.65 \pm 0.9$ & $65.83 \pm 2.0$ & $63.95 \pm 2.0$ \\
\hline 0.4 & $62.07 \pm 2.5$ & $44.51 \pm 0.6$ & $46.39 \pm 0.6$ & $62.69 \pm 1.8$ & $58.93 \pm 1.7$ \\
\hline
\end{tabular}




\begin{tabular}{|l|l|l|l|l|l|}
\hline 0.6 & $58.93 \pm 1.7$ & $39.30 \pm 0.9$ & $44.20 \pm 1.5$ & $59.24 \pm 2.0$ & $54.23 \pm 2.5$ \\
\hline 0.8 & $56.42 \pm 2.0$ & $36.36 \pm 2.6$ & $38.24 \pm 0.9$ & $56.42 \pm 1.4$ & $50.78 \pm 1.9$ \\
\hline 1 & $52.35 \pm 1.7$ & $32.29 \pm 1.3$ & $35.73 \pm 1.6$ & $56.11 \pm 0.9$ & $43.88 \pm 1.7$ \\
\hline 2 & $50.78 \pm 1.4$ & $29.78 \pm 1.4$ & $29.47 \pm 1.3$ & $53.29 \pm 1.7$ & $42.63 \pm 2.0$ \\
\hline 3 & $48.90 \pm 1.9$ & $22.57 \pm 1.9$ & $28.52 \pm 1.3$ & $52.03 \pm 1.5$ & $40.75 \pm 2.0$ \\
\hline 4 & $48.27 \pm 1.4$ & $17.87 \pm 2.1$ & $27.58 \pm 1.3$ & $49.84 \pm 2.4$ & $40.12 \pm 2.4$ \\
\hline 5 & $48.59 \pm 0.9$ & $14.73 \pm 1.0$ & $26.96 \pm 1.0$ & $49.21 \pm 2.4$ & $38.87 \pm 2.0$ \\
\hline
\end{tabular}

Table 4:-Substrate specificity of the kesinai enzyme from Streblus asper -Substarte such as azo-casein, casein, haemoglobin, BSA, and gelatine were used

\begin{tabular}{|l|c|c|c|}
\hline Substrate & Concentration (\%) & Monitoring wave length (nm) & Relative activity (\%) \\
\hline Azo casein & 0.5 & 410 & $100.0 \pm 00$ \\
\hline Casein & 0.5 & 280 & $92.8 \pm 0.5$ \\
\hline Hemoglobin & 0.5 & 280 & $80.1 \pm 1.4$ \\
\hline BSA & 0.5 & 280 & $54.6 \pm 1.4$ \\
\hline Gelatin & 0.5 & 280 & $35.9 \pm 0.6$ \\
\hline
\end{tabular}

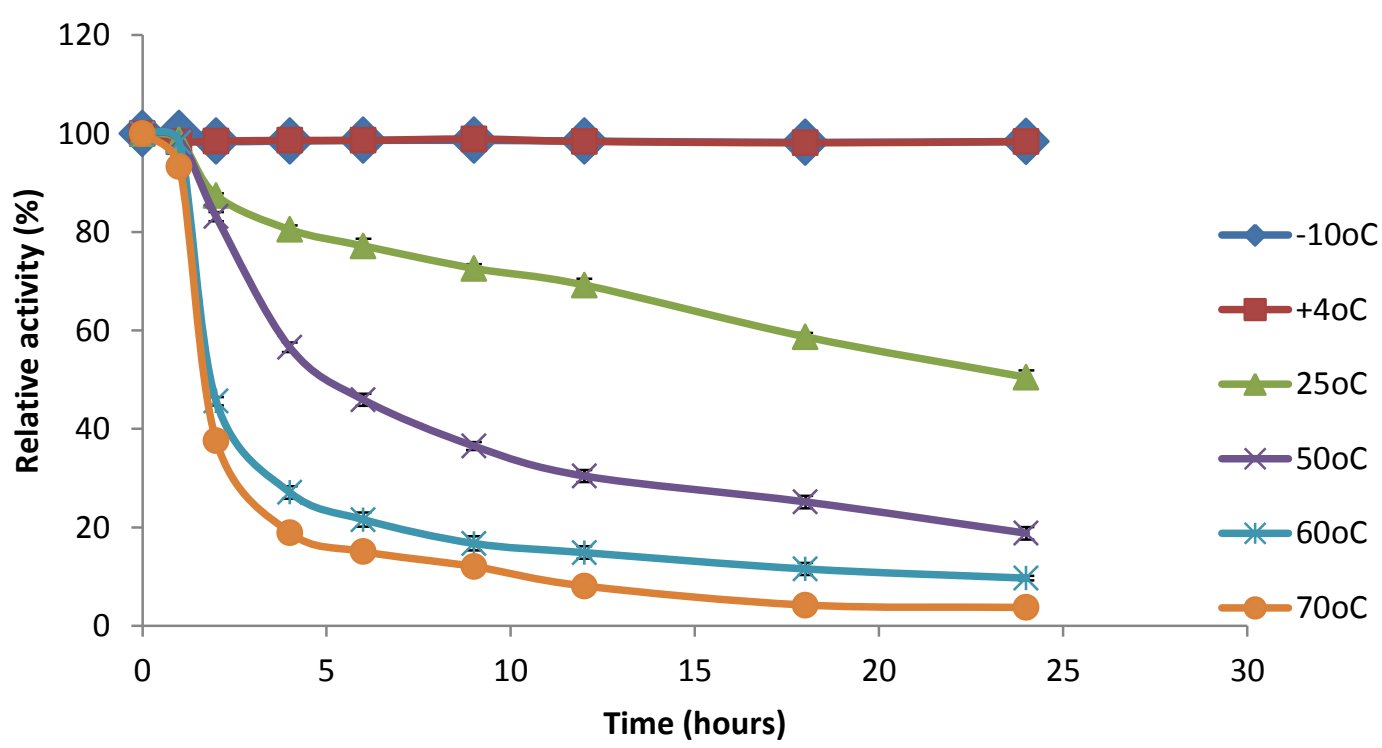

Figure 1:-Effect of Temperature stability of partially purified kesinai enzyme during $24 \mathrm{hr}$ - The temperature was varied from $-10 \mathrm{oC}$ to $70 \mathrm{oC}$ for $24 \mathrm{hr}$ 


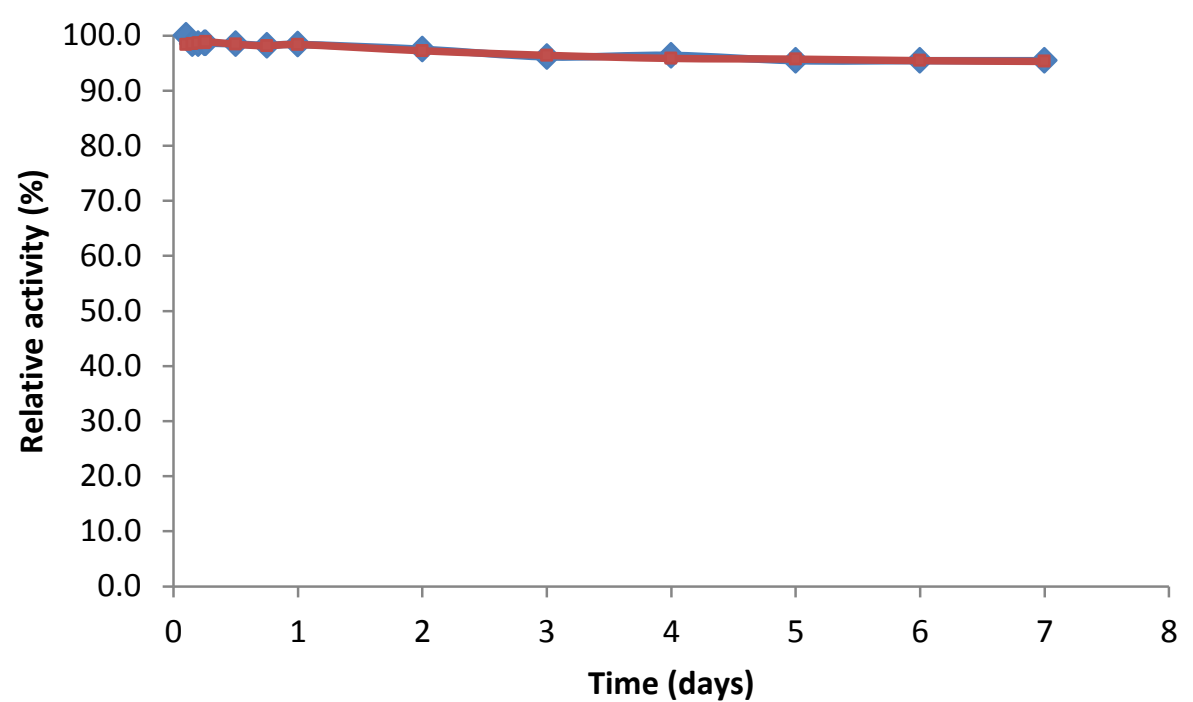

Figure 2:-Storage stability of partially purified enzyme for 7 days -Partially purified enzyme was stored at $-10{ }^{\circ} \mathrm{C}$ and $4{ }^{\circ} \mathrm{C}$ for 7 days

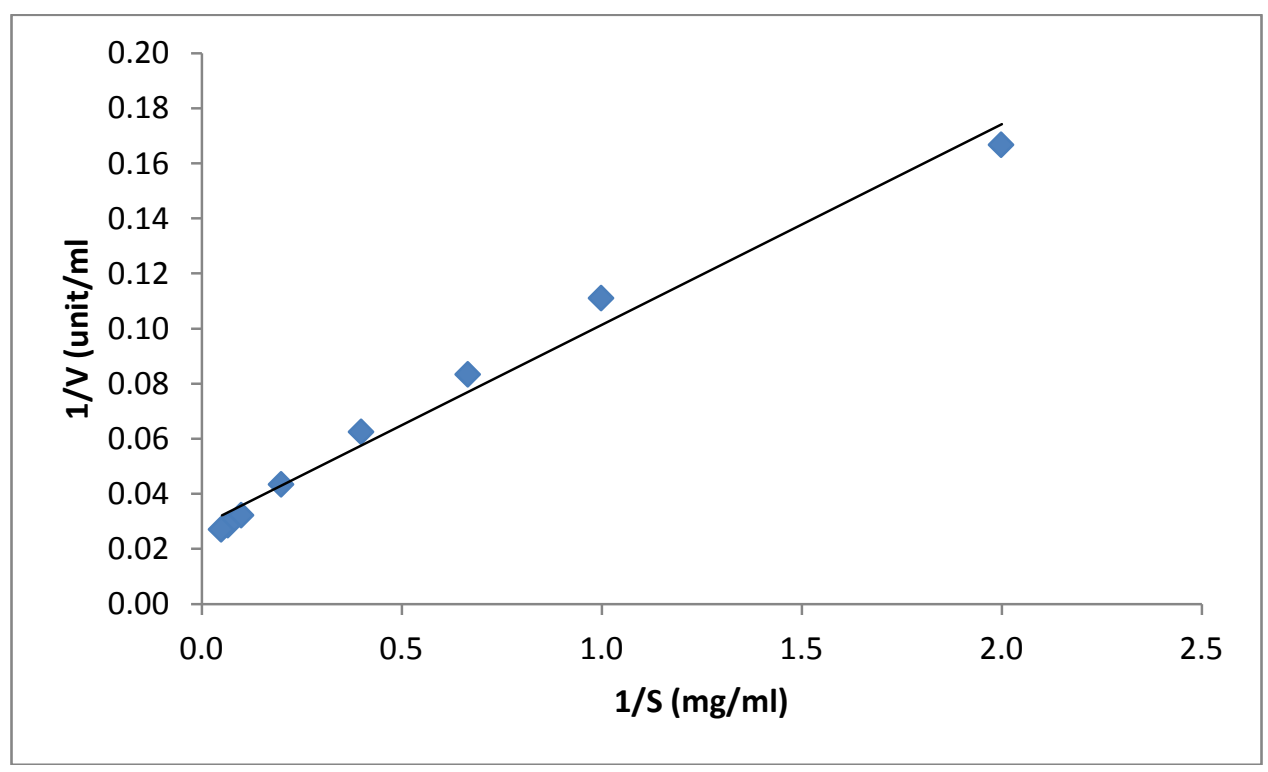

Figure 3:-Lineweaver-Burk plot for reaction versus substrate concentration for partially purified kesinai enzyme substrates was used as azo-casein for Michaelis-Menten equation 


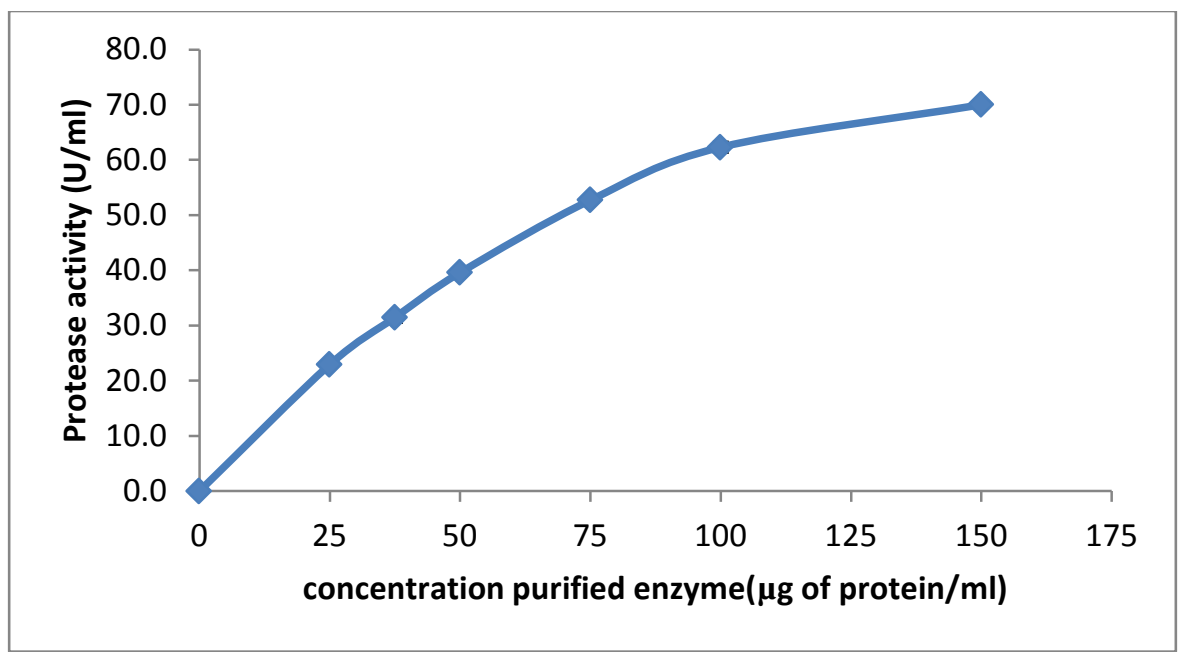

Figure 4:-Activity of partially purified enzyme of different concentration- The range of $0-100 \mu \mathrm{g}$ of protein $/ \mathrm{mL}$ concentration were used

\section{References:-}

1. Baraka Abo El-Yazeed Abd El-Salam., Osama Abd El-Hamid Ibrahim. and Howida Abd El-Razek El-Sayed (2017): Purification and Characterization of Milk Clotting Enzyme from Artichoke (Cynara cardunculus L.) Flowers as Coagulant on White Soft Cheese. International Journal of Dairy Science, 12: 254-265.

2. Bougatef, A., Souissi N., Fakhfakh, N., Ellouz-Triki, Y. and Nasri, M. (2007): Purification and characterization of trypsin from the viscera of sardine (Sardina pilchardus). Food Chemistry, 102: 343-350.

3. Cavalcanti, M. T. H., Teixeira, M. F. S., Lima Filho, J. L. and Porto, A. L.F. (2004): Partial purification of new milk-clotting enzyme produced by Nocardiopsis sp. Bioresource Technology, 93: 29-35.

4. Chazarra, S., Sidrach, L., López-Molina, D. and Rodríguez-López, J.N. (2007): Characterization of the milkclotting properties of extracts from artichoke (Cynara scolymus, L.) flowers. International Dairy Journal, 17 :1393-1400.

5. Chitpinitoyl, S. and Crabbe, M.J.C. (1998): Chymosin and aspartic proteinases. Food Chemistr,y 61: 395-418.

6. Davies, D.R. (1990): The structure and function of the aspartic proteinases. Annual Review Biophysics and Chemistry, 19: 189-215.

7. Egito, A.S., Girardet, J.M., Laguna, L.E., Poirson, C., . Mollé, D., Miclo, L., Humbert, G. and Gaillard, J.L. (2007): Milk-clotting activity of enzyme extracts from sunflower and albizia seeds and specific hydrolysis of bovine k-casein. International Dairy Journal, $17: 816-825$.

8. Elsamani, M. O., Habbani, S. S., Babiker, E. E. and Mohamed Ahmed, I. A. (2014): Biochemical, microbial and sensory evaluation of white soft cheese made from cow and lupin milk. LWT- Food Science and Technology, 59:553-559.

9. Gutiérrez-Méndez,M., Balderrama-Carmona, A., García-Sandoval, S.E., Ramírez-Vigil, P., Leal-Ramos,M.L. and García-Triana, A. (2019): Proteolysis and Rheological Properties of Cream Cheese Made with a PlantDerived Coagulant from Solanum elaeagnifolium. Foods, 8(2): 44-56.

10. Heimgartner, U., Pietrazak, M., Greetsen, R., Brodelius, P., Figueredo, M., Figueiredo, A.C. and Pais, S.S.M. (1990): Purification and partial characterization of milk clotting protease's from flowers of Cynara cardunculus. Phytochemistry, $29: 1405-1410$.

11. Idris, Y.M.A ., Sipat, A.B., Shuhaimi, M. and Yazd, A.M. (1999): Inhibition of enzymatic Browning during the extraction of a milk coagulation protease from Streblus asper (Kesinai). Pakistan Journal of Biology Sciences, 2: $378-381$.

12. Jacob, M., Jaros, D. and Rohm, H. (2011): Recent advances in milk clotting enzymes. International Journal of Dairy Technology, 64:14-33.

13. Khan, H., Subhan, M., Mehmood, S., Durrani, M. F., Abbas, S. and and Khan, S. (2008): Purification and Characterization of Serine Protease from Seeds of Holarrhena antidysenterica. Biotechnology, 7: 94-99.

14. Lineweaver, H. and Burk, D. (1934): The determination of enzyme dissociation constant. Journal of American Chemical Society, 56: 658-666. 
15. Lowry, O.H., Rosebrough, N.J., Farr, A.L. and Randall, R.J. (1951): Protein measurements with the Folin phenol reagent. Journal biological chemistry, 193: 265-275.

16. Manap, M.Y., Sipat, A., Lajis, M.N.H and Ibrahim, F.H. (1992): Coagulation of milk using plant (Streblus asper) Extract Scienza Etecnica Lattiero- Casearia, 3: 37-43.

17. Matta, H. and Punj, V. (1998): Isolation and partial characterization of a thermostable extracellularprotease of Bacillus polymyxa B-17. International Journal of Food Microbiology, 42 : 139-145.

18. Michail, M., Vasiliadou, M. and Zotos, A. (2006): Partial purification and comparison of precipitation techniques of proteolytic enzymes from trout (Salmo gairdnerii) heads Food Chemistry, 97 :50-55.

19. Mohamed Ahmed, I.A., Morishima, I., Babiker, E.E. and Mori, N. (2009): Characterization of partially purified milk-clotting enzyme from Solanum dubium Fresen seeds. Food Chemistry, 395-400.

20. Nasr, A. I. A. M., Ahmed., I A. M. and Hamid, O. I. A. (2016): Characterization of partially purified milkclotting enzyme from sunflower (Helianthus annuus) seeds. Food Science and Nutrition, 4(5):733-741.

21. Ogundiwin, J. O. and Oke, O.L. (1983). Factors affecting the process of Wara-A- Nigeria white Cheese. Food Chemistry, $11: 1-13$.

22. Raposo, S. and Domingos, A. (2008): Purification and characterization milk-clotting aspartic proteinases from Centaurea calcitrapa cell suspension cultures. Process Biochemistry, 43:139-144.

23. Rastogi, S., Kulshreshtha, D.K. and Rawat, A.K. S. (2006): Streblus asper Lour. (Shakhotaka): A Review of its Chemical, Pharmacological and Ethnomedicinal Propertie;. eCAM, 3(2):217-222.

24. Rao, C.S., Sathish, T., Ravichandra, P. and Prakasham, R.S. (2009): Characterization of thermo- and detergent stable serine protease from isolated Bacillus circulans and evaluation of eco-friendly applications. Process Biochemistry, 44 : 262-268.

25. Roseiro, L.b., Barbosa, M., Ames, J.M. and Wilbey, R. A. (2003): Cheese making with vegetable coagulants The use of Cynara L . for the production of ovine milk cheese. International Journal of Dairy Technology, 56: 76-85.

26. Sarath, G., De La Motte, R.S. and Wagne, F.W. (1989): Protease assay methods. In: Beynon, R.J., Bond, J.S, editors. Proteolytic enzymes. Oxford, U.K.: OIRL Press. 25-56.

27. Sastry, K.J. (1979): Studies on the milk clotting enzymes from Bacillus megaterium K-40. Ph.D. Thesis, Kurukshetra University, Kurukshetra, India.

28. Senthilkumar, S., Ramasamy, D. and Subramanian, S.(2006): Isolation and Partial Characterisation of Milkclotting Aspartic Protease from Streblus asper. Food Science and Technology International, 12: 103 -109.

29. Shah, M. A., Mir, S. A. and Paray, M. A. ( 2014): Plant proteases as milk-clotting enzymes

30. in cheesemaking: a review. Dairy Science and Technology, 94:5-16.

31. Shieh, C. H., Thi, L. A. P. and Shih, I. L. (2009): Milk-clotting enzymes produced by culture of Bacillus subtilis natto. Biochemical Engineering Journal 43: 85-91.

32. Silva, S. V., Barros, R. M. and Malcata, F. X. (2002): Hydrolysis of caseins by extracts of Cynara cardunculus precipitated by ammonium sulphate. Journal of Food Science, 67: 1746-1751.

33. Silva, S. V. and Malcata, F. X. (2000): Action of cardosin A from Cynara humilis on ovine and caprine caseinates. Journal of Dairy Research, 67: 449-457.

34. Taweechaisupapong, S., Wongkham, S., Chareonsuk, S., Suparee, S., Srilalai, P. and Chaiyarak, S. (2000): Selective activity of Streblus asper on Mutans streptococci, Journal of Ethnopharmacology,70:73-79.

35. Yadav, S.C., Pande, M. and Jagannadham, M.V.(2006): Highly stable glycosylated serine protease from the medicinal plant Euphorbia milii. Phytochemistry, 67 : 1414-1426.

36. Zotos, A. and Taylor, K. D.A. (1996): Partial purification and characterization of proteases from Norway lobster (Nephrops norvegicus) and their role in the phenolase activation process. Food Chemistry, 56: 61-68. 